\section{Management of small choroidal melanocytic tumour}

Papadopoulou et $a l^{1}$ are to be congratulated for submitting an informative article regarding the management of small choroidal melanoma with pertinent discussion and various educational points to remember. We were, however, surprised, not to find the use of OCT (optical coherence tomography) as part of the management to help the diagnosis or in the discussion section. The authors ${ }^{1}$ correctly highlight the use of B-scan ultrasound to document the echographic features of melanocytic tumours; however, the use of OCT is complementary to human observation, echography and fluorescein angiography in cases of shallow subretinal fluid for multiple retinal pathology including small choroidal melanomas. Latest-generation OCT machines are quick, non-invasive and reliable with good reproducibility. With availability of enhanced depth-imaging mode, scanning of the choroid is now feasible. This has been well described by Shields et $a l^{2-5}$ and we find their mnemonic TFSOM (presence of three or more features suggests high risk of small choroidal melanoma vs benign choroidal naevus) very useful for risk stratification in choroidal melanocytic tumours. (TFSOM=T, thickness $>2.0 \mathrm{~mm}$; F, subretinal fluid; S, symptomatic; $\mathrm{O}$, orange pigmentation; $\mathrm{M}$, margin touching the optic nerve.) Also the referral guidelines developed by the ocular oncology group, for the Royal College of Ophthalmologists UK, ${ }^{6}$ recommend referral for specialist oncology opinion of any suspicious choroidal naevi $>2.0 \mathrm{~mm}$ thickness or thickness $>1.5 \mathrm{~mm}$ if associated with serous retinal detachment and orange pigment. OCT to detect serous retinal detachment (subretinal fluid) should be used to improve management of melanocytic choroidal lesions.
Department of Ophthalmology, James Paget University Hospital NHS Trust, Great Yarmouth, Norfolk, UK

Correspondence to Dr Muhammad S Raja, Department of Ophthalmology, James Paget University Hospital NHS Trust, Lowestoft Road, Great Yarmouth, Norfolk NR317RD, UK; docraja@hotmail.com

Contributors MSR was involved in conception, literature search and manuscript design. CG and BJLB oversaw manuscript revision. All authors were involved in editing and revising the draft paper, and approval for the final draft was obtained from all authors.

Competing interests None.

Provenance and peer review Not commissioned; externally peer reviewed.

\section{6 OPEN ACCESS}

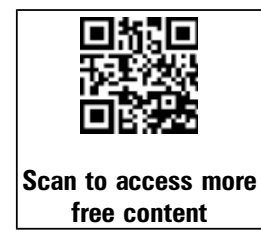

Open Access This is an Open Access article distributed in accordance with the Creative Commons Attribution Non Commercial (CC BY-NC 3.0) license, which permits others to distribute, remix, adapt, build upon this work non-commercially, and license their derivative works on different terms, provided the original work is properly cited and the use is non-commercial. See: http:// creativecommons.org/licenses/by-nc/3.0/

To cite Raja MS, Goldsmith C, Burton BJL. Br J Ophthalmol 2013;97:241.

Accepted 10 October 2012

Br J Ophthalmol 2013;97:241.

doi:10.1136/bjophthalmol-2012-302714

\section{REFERENCES}

1 Papadopoulou D, Moulin AP, Zografos L, et al. How would you manage this small choroidal melanocytic tumour? Br J Ophthalmol. Published Online First: 27 Sep 2012. doi:10.1136/bjophthalmol-2012-302329.

2 Shields CL, Furuta M, Thangappan A, et al. Metastasis of uveal melanoma millimeter-by-millimeter in 8033 consecutive eyes. Arch Ophthalmol 2009;127:989-98.

3 Shields CL, Kaliki S, Rojanaporn D, et al. Enhanced depth imaging optical coherence tomography of small choroidal melanoma. Arch Ophthalmol 2012;130:850-6.

4 Shah SU, Kaliki S, Shields CL, et al. Enhanced depth imaging opticalcoherence tomography of choroidal nevus in 104 cases. Ophthalmology 2012;119:1066-72.

5 Repucci M, Rojanaporn D, Shields CL. Shaggy photoreceptors with small choroidal melanoma. Retina Today 2012;7:45-7.

6 National Ocular Oncology Group. Referral Guidelines for Adult OcularTtumours Including Choroidal Naevi. Royal college of Ophthalmologists, 2009. http://www. rcophth.ac.uk (accessed 6 Oct 2012). 